\title{
INNOVATION PROCESSES AND CONDITIONS FOR FINANCING INNOVATIONS IN BULGARIA
}

\author{
T. Yosifov ${ }^{*}$, G. Taneva ${ }^{2}$ \\ Department of Finance and Accounting, Faculty of Economic and Social Sciences, Plovdiv University \\ "Paisii Hilendarski", Plovdiv, Bulgaria
}

\begin{abstract}
The assessment of innovation processes in the country should be based on the context in which the country's economy has been developing since 2009. From the beginning of that period until 2015 the National Statistical Institute reported about seven years in which steady economic growth would not be achieved. Internal consumption and investment activity remain low due to the lack of new business projects of good quality. Under such conditions, the innovations and the development of entrepreneurial activity develop exceptionally slowly due to the problems mentioned above, but not because of a purposeful government policy.

The present paper is aimed at presenting an analysis of innovation processes in the country without going deep into the main problems that innovative enterprises in the country face.
\end{abstract}

Key words: innovation, business environment, risk capital.

\section{INTRODUCTION}

The legislative framework that sets the course of innovations in the country contributes to innovation development. However, the progress in this area is determined mainly by external for the country factors: the harmonization of patent laws with patent laws in the European Union (EU); draft documents developed by non-governmental teams of experts, including strategies for developing high technologies and clusters; documents binding the country to put European funds to use aided by some national instruments: OP Competitiveness for the program period 2014 2020, OP Innovations and Competitiveness, OP Science and education for smart growth and OP Innovation strategy for smart specialization for the program period 2014 2020 .

Over the last decade, national political determination to develop science, technologies and innovations has been expressed in three documents only: Law for the Encouragement

\footnotetext{
*orrespondence to: Trayan Yosifov, $\mathrm{PhD}$, Department of Finance and Accounting, Faculty of Economic and Social Sciences, Plovdiv University "Paisii Hilendarski", Plovdiv 4000, Bulgaria., 24 Tsar Asen St., tel. 032/ 261471, E-mail: t_yosifov@abv.bg
}

of Research (2003), Innovation strategy (2004) and National Strategy for Research (2011). In this respect, it is necessary to mention that the realization of these documents is not supported by steady and consistent financial and administrative commitment of the government relating the realization of set goals and given tasks to the concrete political and economic environment. With respect to these facts, it is impressing that a great part of Bulgarian enterprises increase their innovation activity. This is shown in the statistical information about the expenditure of enterprises on scientific research and development activities (SRDA) presented in graph 1.

As it can be seen in the graph, the data about the innovation expenditure of the enterprises stand in contrast to the ones in the state sector and higher education. Moreover, after 2009, there was a decrease in the average annual values of state expenditure, which can be explained by the influence of the crisis on economics public expenditure and the fall-off of public expenditure. An important criterion in studying innovation processes in the country is the size of enterprises based on the "number of people busy with SRDA. The data are presented in graph 2. 
YOSIFOV T., et al.

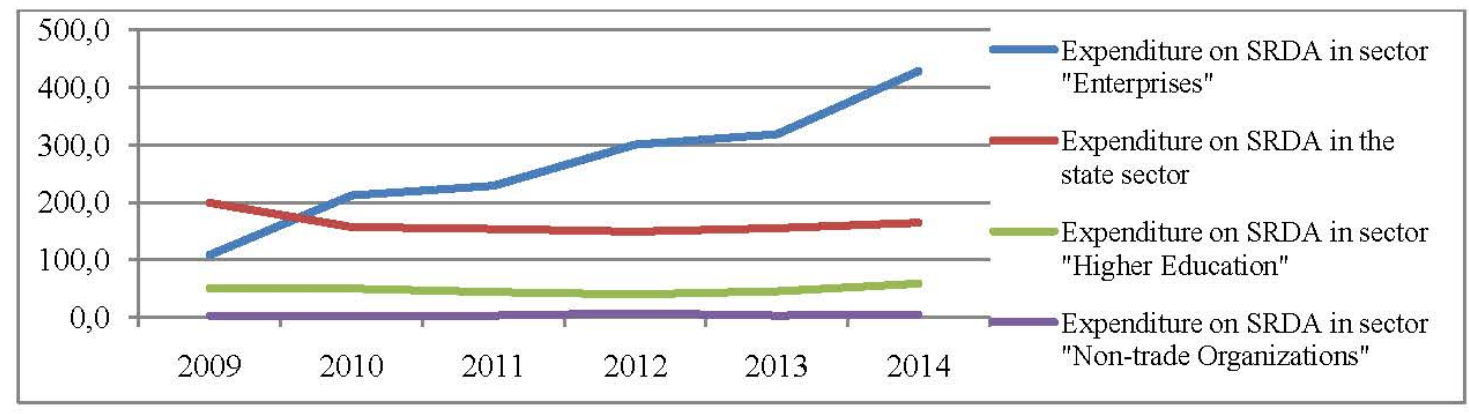

(millions BGN)

Source: NSI (Expenditure on SRDA by types and sectors), 2015.

Graph 1. Total expenditure on SRDA by types and sectors

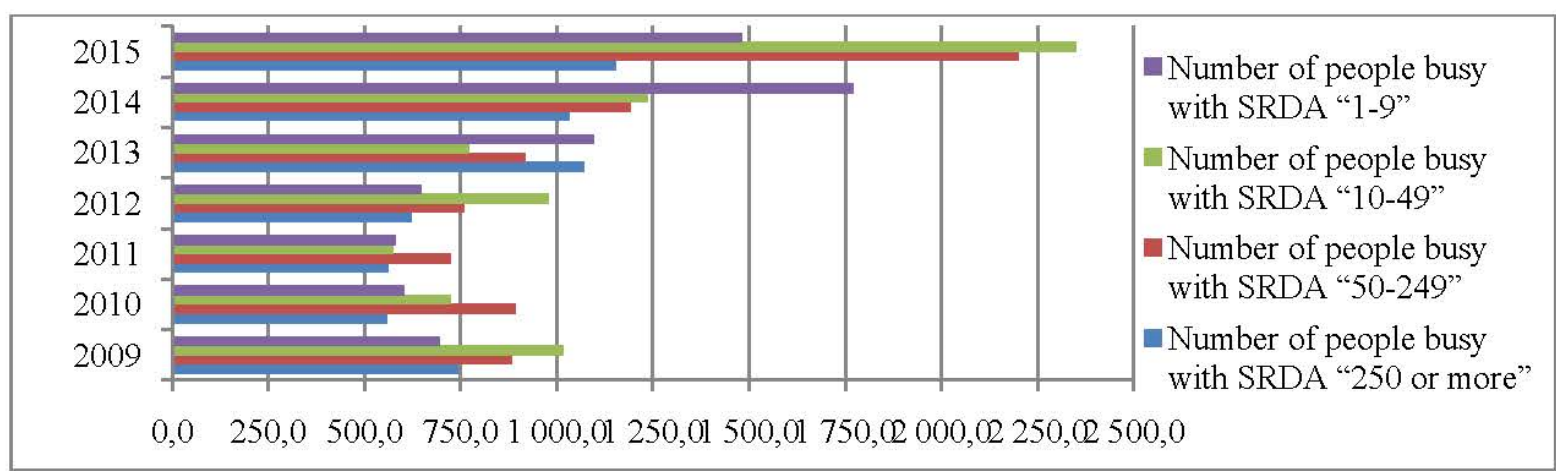

(thousands)

Source: NSI (Personnel, busy with SRDA), 2016.

Graph 2. Distribution of innovations by enterprises according to the number of people busy with SRDA

The data above are representative and allow the following conclusions to be drawn:

- First, for the period the graph presents, innovation expenditure was reported by 20,642 enterprises, which account for 7 per cent of the total number of trade companies registered in the country.

- Second, the share of the enterprises realizing an innovation with a number of people busy with it below 50 is almost 80 per cent of the total number of innovation enterprises in the country. This fact is significant for the importance of innovations for the development of small and average-size enterprises in the country.

- Third, the increase in the number of innovation enterprises at the end of the examined period might be due to the tendency towards the improvement of the external components of business environment, which was particularly indicative exactly in that period.
- Forth, the increase in the share of innovation enterprises in the country can be achieved by using the reserves largely in terms of using the funds provided by the EU operation programs as well as the opportunities provided by the funds for risky capital (FRC). Here, it is necessary also to consider how important it is to improve the management of Bulgarian enterprises as it is a precondition for attracting and retaining the investment interest of risky companies.

In order to make a more detailed analysis of innovation activity in the country, it is important to examine those technological areas that generate the main part of patent activity. The data for the period between 2001 and 2013 are presented in Table $\mathbf{1}$ in accordance with the classification indication: International Patent Classification (IPC). 
YOSIFOV T., et al.

Table 1. Top ten technological areas (class, according to IPC) of patent activity in Bulgaria by the end of 2013.

\begin{tabular}{|l|l|l|l|}
\hline No & $\begin{array}{l}\text { Class in } \\
\text { IPC }\end{array}$ & Name & Percentage \\
\hline 1. & C07 & $\begin{array}{l}\text { Organic chemistry: general methods, acyclic, carbocyclic, } \\
\text { heterocyclic compounds, sugar, steroids, proteins. }\end{array}$ & 23,9 \\
\hline 2. & A61 & Human and veterinary medicine, hygiene, stomatology, medicines. & 22,5 \\
\hline 3. & B65 & Transportation, packaging, and storage of materials. & 3,8 \\
\hline 4. & C12 & $\begin{array}{l}\text { Biochemisty, beer, alcoholic drinks, wine, microbiology, } \\
\text { enzimology, genetic engeneering. }\end{array}$ & 3,6 \\
\hline 5. & A01 & $\begin{array}{l}\text { Agriculture, forestry, animal farming, hunting, fishing, pesticides, } \\
\text { herbicides, desimfectants. }\end{array}$ & 3,3 \\
\hline 6. & H04 & $\begin{array}{l}\text { Technique of electric connections, transmission of signals, secret } \\
\text { connection, telephone connection, TV telecommunications. }\end{array}$ & 2,5 \\
\hline 7. & H01 & $\begin{array}{l}\text { Basic elements of electric equipment: cables, conductors, resistors, } \\
\text { magnets, detectors, transformers, switches, resonators, etc. }\end{array}$ & 2,0 \\
\hline 8. & G01 & $\begin{array}{l}\text { Measurement of physical quantities. } \\
\text { Food and food products, processing, milk, butters, coffee, tea, } \\
\text { chocolate, sugar products. }\end{array}$ & 1,7 \\
\hline A23 & $\begin{array}{l}\text { Methods and aids for physical and chemical processes: melting, } \\
\text { moulding, mixing. Equipment. }\end{array}$ & 1,7 \\
\hline Total: & \multicolumn{2}{|l}{ B01 } & 66,7 \\
\hline
\end{tabular}

Source: Innovations.bg, 2014.

The data show that the first four technological fields form almost 55 per cent of all the patents issued in the country between 2001 and 2013. This fact testifies that local manufacturers are relatively unattractive and it gives justified arguments allowing to outline those economic sectors that attract local and foreign investors' interest and form the main part of the country's export respectively. It can be assumed that those enterprises which function in the economic sectors mentioned above are a priority goal of investment for risky funds.

It is also interesting to know which countries form the main part of foreign patent activity in Bulgaria. The data about this are presented in graph 3.

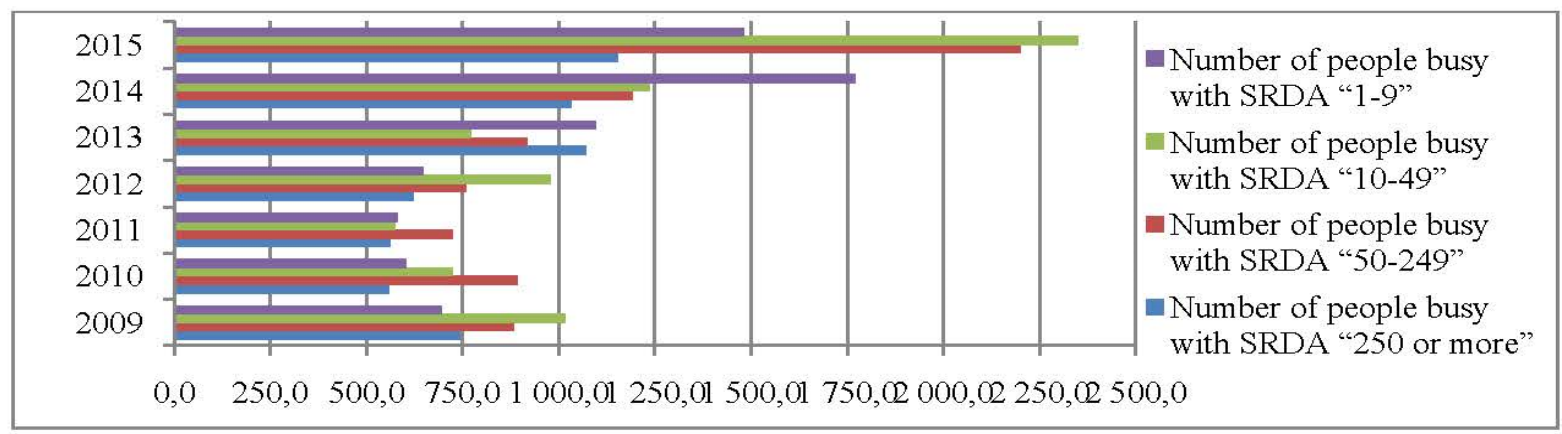

(thousands)

Source: NSI (Personnel, busy with SRDA), 2016.

Graph 3. Foreign patent activity in Bulgaria between 2001 and 2013 (number

The data show that EU-member states are the biggest foreign net owner of patents in the country. The leading position is for Germany, which has one fifth of all the patents registered in the country.
The first five most active countries in the area of patents, to which Belgium and Austria can be added, are the ones forming the group of countries which are also the main foreign 
investors in the country. This connection is not accidental as, through the joint management of technological and financial assets, foreign companies investing in Bulgaria use long-term well-planned strategies for technological and economic presence on the local market.

A summarizing index of the general innovation activity is Innovation Index of Bulgarian Enterprises (IIBE), which is periodically identified on the basis of empirical research conducted by the Applied Studies and Communication Foundation (ASCF). It is defined as measurement of innovation activity period. on a company basis in Bulgaria and aggregates seven different types of innovations realizing by enterprises: product, process, management and market innovations.

The data of the survey comprising two comparable periods, 2009 and 2014, show that there are some positive tendencies, quite weak though (graph 4). The reason is the increase in the innovation activity coefficient of Bulgarian enterprises which is proved by the expenditure on SRDA for the same

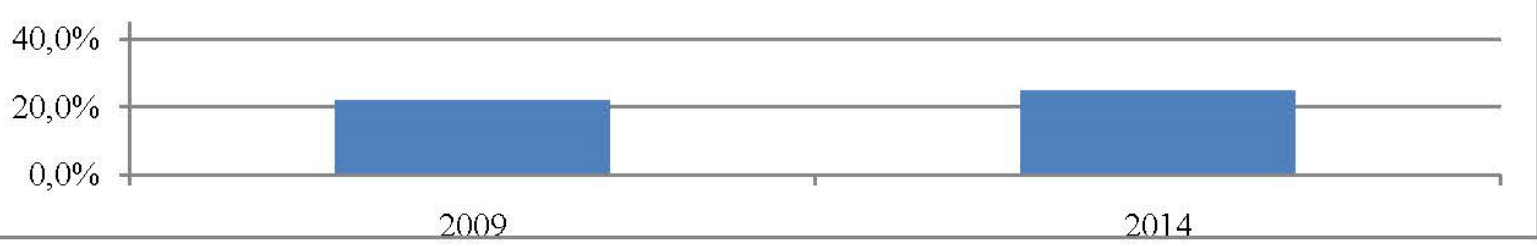

Source: Applied Studies and Communication Foundation (ASCF), 2014.

Graph 4. Innovation index 2009 - 2014.

The rise of the index in 2014 in comparison with 2009 can be explained mainly with the increased innovation activity of Bulgarian enterprises realizing a greater number of innovations which are also more varied. Such an increase can be interpreted as striving for improving their competitive position on internal and international markets. It is also a direct consequence of Bulgaria's membership in the EU and the access to the common European market respectively.
The increase in the resources of SRDA for the period 2009 - 2014 was accompanied by improving the financing of institutional sectors mainly due to the access to external financing (mostly through structure and cohesion funds). In a regional aspect, there are not such signals for a similar structural improvement despite the increase in the enterprises' budget of the resources for SRDA. The data on the regional structure of the expenditure on SRDA are presented in graph $\mathbf{5}$.

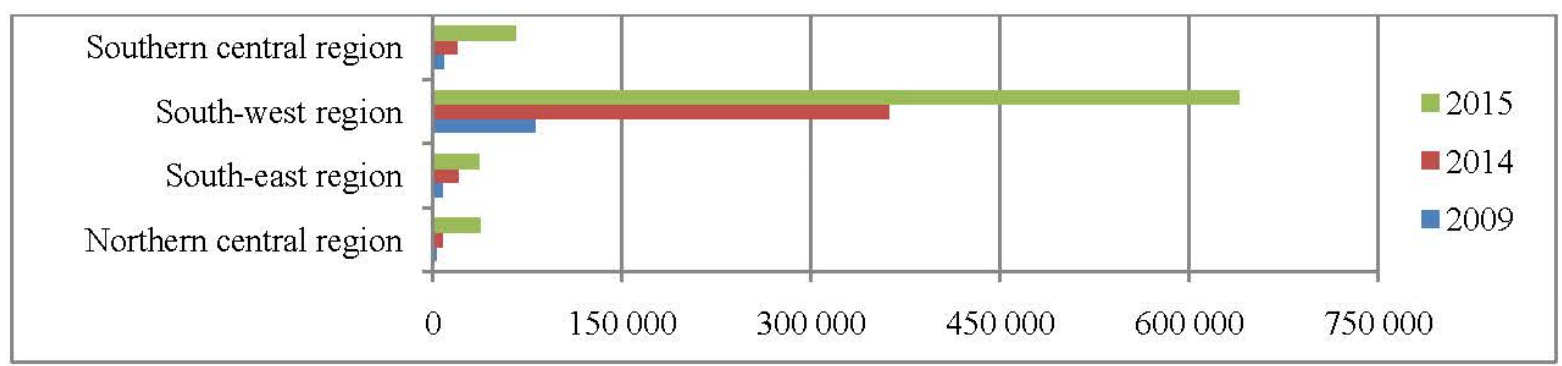

Source: NSI (Scientific research and development activity), $2016 .{ }^{1}$

Graph 5. Regional structure of the expenditure on SRDA, sector Enterprises (thousands lv.)

${ }^{I}$ There are no data on north-east and nortt-west region

The data presented above show that the main part of financing for implementing SRDA continues to be very much concentrated just in the region around the capital attracting human resource to scientific research units in it. This casts doubt on the adequate usage and development of the research and innovation potential of other regions.

Despite the positive pace of changes of the expenditure on SRDA at regional level, the 
country lags behind considerably regarding the funds it puts in use for innovations in accordance with the programs of the EU.

There are data of European Commission (EC) about the funds paid by the Commission and distributed among the theme areas defined by EC. They show that scientific research, technological development, innovations and entrepreneurship are Bulgaria's priorities. Only
4.4 per cent of the money put in use by the beneficiaries in the country and allocated by European Fund for Regional Development, Cohesion Fund (CF) and European Social Fund have been used for encouraging companies operating in the areas mentioned above. Therefore the country is in the last place among the countries of the EU. The data are presented in graph 6.

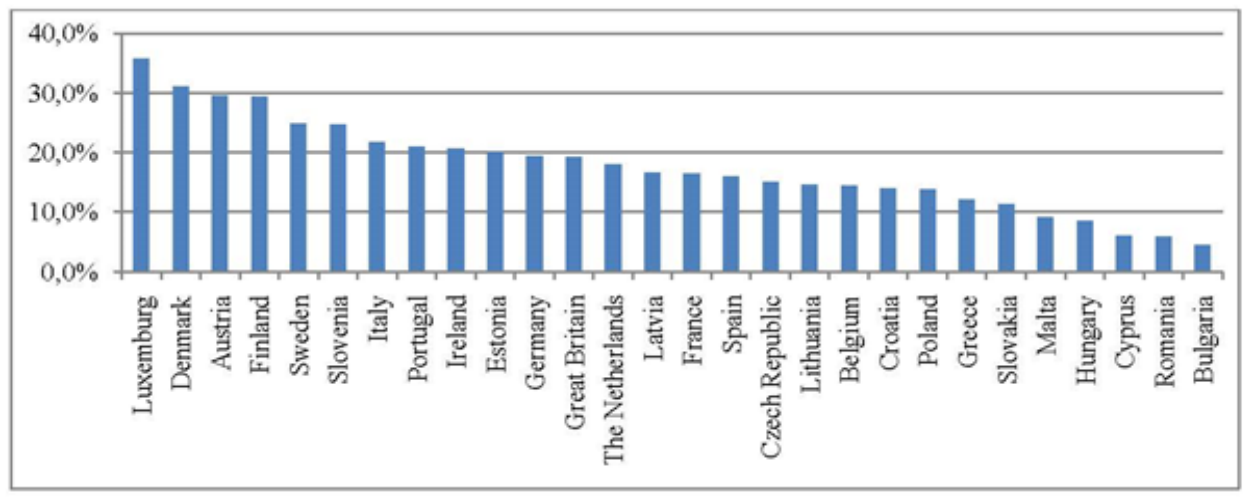

Graph 6. Financing in theme area Science, Research and Technological Development Activities, Innovations and Entrepreneurship in the operation programs for $2007-2014$

Conclusion

The development of innovations in the country is a direct consequence of the quality of the environment in which business and state policies of the country function in this direction, including the measures of EC for encouraging member-states' innovation activity. In relation to this, it is possible to draw the following conclusion: the increase in the innovation potential of Bulgarian economy is related largely to the activities of country's government aimed at improving business environment as well as at particular long-term policies on encouraging innovations in the country.

Another important conclusion is related to the great opportunities for increasing the innovation potential of enterprises with risky financing. Knowing well the authors who write about financing innovations with risky capital makes, it possible to conclude that the interest of country's scientific community should turn to this area. The lack of a sufficient number of studies in this field as well the importance of risky financing for developing the innovations in leading European economies, and in the USA in particular, makes it necessary to do well-focused practically oriented research work.

\section{REFERENCES}

1. Blagoev, D., Innovation and Innovation of the Company, Avangard Prima, S., 2013.

2. Boes, W., Chobanov, A., Simeonova, S., Bozhilov, D., Venture Capital Financing -
Leadership of the Bulgarian Entrepreneur, Ursit Ltd., Sofia, 2005.

3. Georgiev, I., Basic Innovation Models of Industrial Companies in Bulgaria, Collection of Papers: Prerequisites and Opportunities for Industrial Growth in Bulgaria, University of National and World Economy, Sofia, 2013.

4. Mishev, G., Statistical characterization for the business environment based on survey data, Economic Alternatives, University of National and World Economy, Sofia, 2010.

5. Bompers and Josh Lerner, "The Venture Capital Revolution", Journal of Economic Perspectives, June 2001.

6. Calamel, L., Defelix, C., Picq, T., Retour, D., Inter-organization project in French innovation clusters: The construction of collaboration international Journal of Project, Volume 30, Issue 1, January 2012.

7. Fryman, M., Quality and Process Improvement, Delmar, 2002.

8. OECD (2005) Guidelines for Collecting and Interpreting Innovation Data. Oslo Manual, Third Edition. OECD/European Communities.

9. EUROSTAT.

10.Innovations.bg.

11.NSI.

12.Patent Office of Republic of Bulgaria.

13.Applied Studies and Communication Foundation. 
YOSIFOV T., et al. 